\title{
Indhold 2011
}

\section{Artikler}

Balvig, Flemming, Helgi Gunnlaugsson og Henrik Tham: Ikke kun strenghed - replik om de nordiske retsbevidsthedsundersøgelser

Boucht, Johan: Om objektivitetsprincipen i den polisiära verksamheten -

Utkast till problemställningar

Christophersen, Jan Georg: Mellom profitt og moral: Regulering og kon-

troll av ulovlig, urapportert og uregulert friske (UUU fiske)

Greve, Vagn: Retten og samfundet

Gøtze, Michael: Retlige grænser for brug af straffeattester på arbejdsmar-

kedet

Hansen, Helen Ornemark: Likhet inför lagen - lika inför straffet? - Föroch nackdelar med individanpassad rättssakerhet

Johnsen, Berit: Forvaring - fra særreaksjon og »straff« til lovens strengeste straff: Ett skritt frem eller ett tilbake?

Myhrer, Tor-Geir: Sentervekternes polisiære fullmakter - Grunnlag og grenser

Olaussen, Leif Petter: De nordiske rettsbevissthetsunders $ø$ kelsene - noen metodekristiske betraktninger

Olaussen, Leif Petter: Tilsvar til replikk om rettsbevissthetsundersøkelsene.

Sunde, Inger Marie: Automatisert rettshåndhevelse på nettet

Suominen, Annika: Om arbetet med nordisk rätt - några personliga reflektioner

\section{Boganmeldelser}

Beckett, Kathrine og Steve Herbert: Banished. The New Social Control in

Urban America

Chambliss et al. (red.): State Crime in the Global Age

Hauge, Ragnar: Rus och rusmidler gjennom tidene

Jakobsen, Janne og Peter Scharff Smith: Børn af fængslede - en informa-

tions- og undervisningsbog

Jewkes, Yvonne \& Majid Yar (eds.): Handbook of Internet Crime

Knepper, Paul: The Invention of International Crime

Lalander, Philip: Respekt - Gatukultur, ny etnicitet och droger 
Loftus, Bethan: Police Culture in a Changing World ................................... 188

Mathisen, Gjermund: Utlevering for straffbare forhold ............................. 308

Nedergaard, Peter: Lissabontraktaten - en politologisk analyse ................. 313

Nygard, Lars-Jonas: Juryen for fall ......................................................... 202

Pakes, Francis: Comparative Criminal Justice .......................................... 311

Ryberg Jesper (red.): Løsladt - og hvad så? ............................................... 191

Senholt, Leif (red.): Fængselshistorisk Selskab 2008 .................................. 195

Stevnsborg, Henrik: Politi 1682-2007 ....................................................... 71

White, Rob (red.): Global Environmental Harm ........................................... 79

\section{Debat}

Levander, Sten: God vilja räckte inte - ett personligt perspektiv på svensk rättspsykiatri

\section{Diverse}

Till minne av Hans Thornstedt .....................................................................

De nordiske kriminalistforeninger 2011 ..................................................... 88

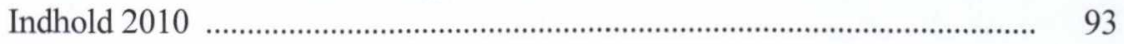

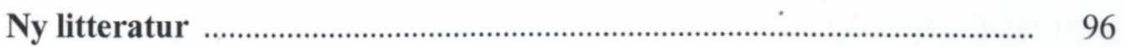

